\title{
Profound first-degree atrioventricular block
}

\author{
Waqas Akhtar, Krishnaraj Sinhji Rathod, John Alexander, Fahad Farooqi
}

Department of Cardiology, Barking Havering Redbridge University Hospital NHS Trust, Ilford, Essex, UK

\section{Correspondence to} Dr Krishnaraj Sinhji Rathod, krishnarajrathod@gmail.com

\section{DESCRIPTION}

We present a case of profound first-degree heart block with the longest reported PR interval $(640 \mathrm{~ms})$. The aetiology of extreme first-degree block in our case was multifactorial, due to senile conductive system fibrosis, hypothermia and digoxin therapy.

A woman in her 90s presented with syncopal episodes secondary to bradycardia. She was mildly hypothermic and her only rate-limiting medication was low-dose digoxin (62.5 $\mu$ g once daily).

She had a medical history of severe ischaemic left ventricular systolic dysfunction and hypertension.

Investigations revealed acute kidney injury with a serum digoxin level of $1.8 \mathrm{ng} / \mathrm{mL}$. Her electrolytes were normal and she was not hypothyroid.

The 12 Lead ECG (figure 1) revealed bradycardia (54 bpm), slow and irregular P wave frequency due to sinus node disease, profound first-degree heart block of $640 \mathrm{~ms}$, broad left bundle branch block with leftward axis deviation. $\mathrm{P}$ waves occasionally concealed in preceding QRS complex.

She was rewarmed, fluid resuscitated and digoxin withheld. The PR interval recovered significantly to $300 \mathrm{~ms}$ and she did not proceed to a pacemaker. She was readmitted a few weeks later with pneumonia and unfortunately she passed away.
First-degree heart block is due to delayed conduction from the sinus node through to the atrioventricular node. It occurs in healthy athletes as well as in diseased hearts and is the most common conduction disturbance (prevalence of 1.1\%).

Markedly prolonged PR interval may result in symptoms of pacemaker syndrome ${ }^{1}$ and reduced exercise tolerance. Syncope may result from transient high-degree atrioventricular block.

A prospective cohort study ${ }^{2}$ found that individuals with PR prolongation had increased risks of atrial fibrillation and all-cause mortality.

\section{Learning points}

First-degree heart block is due to delayed conduction from the sinus node through to the atrioventricular node.

- It occurs in healthy athletes as well as in diseased hearts and is the most common conduction disturbance (prevalence of $1.1 \%$ ).

- Syncope may result from transient high-degree atrioventricular block.

- Second-degree type 1 sino-atrial block is a very similar condition often missed because of minimal clinical significance.
To cite: Akhtar W, Rathod KS, Alexander J, et al. BMJ Case Rep Published online: [please include Day Month Year] doi:10.1136/bcr-2013010474

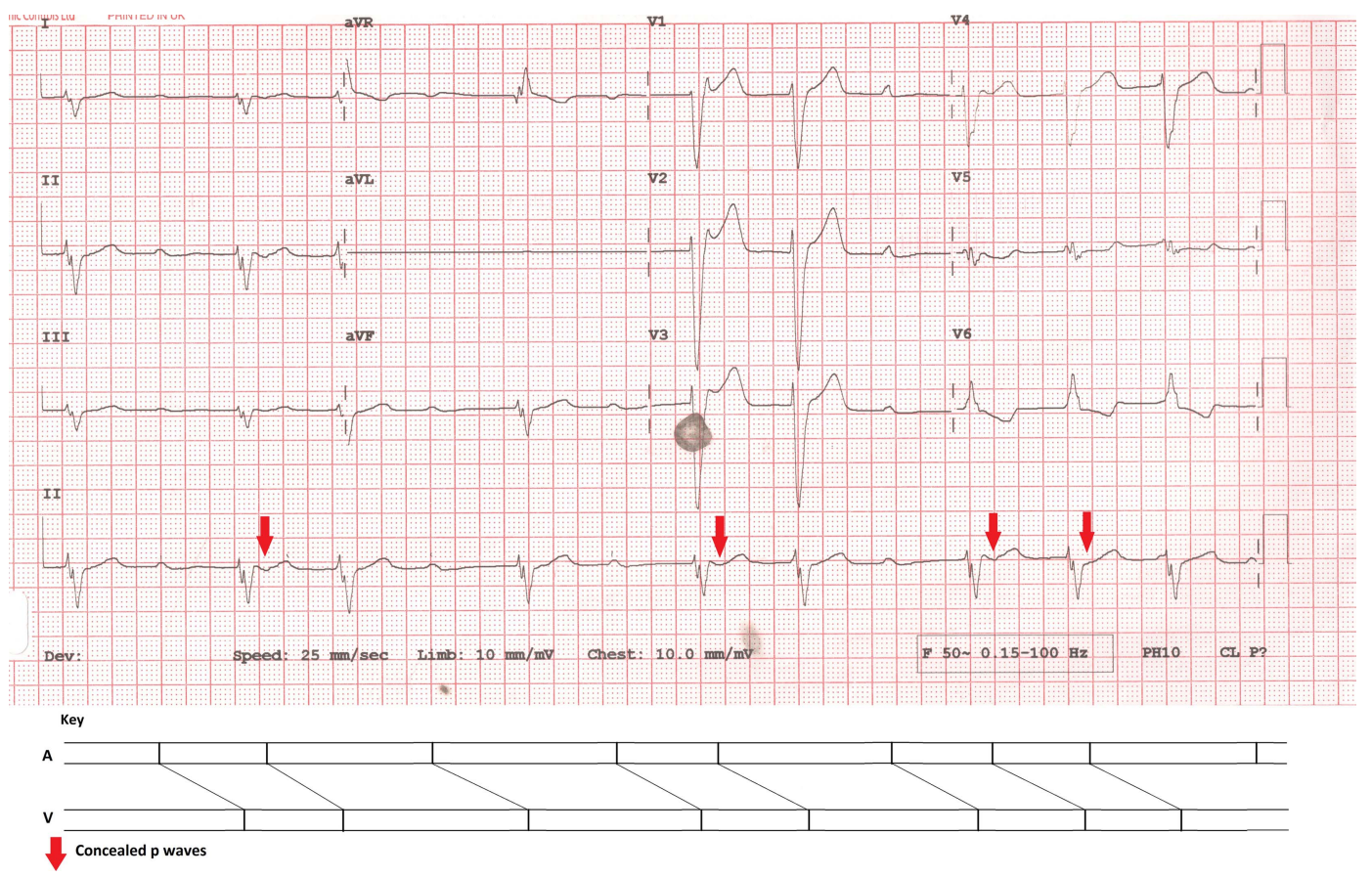

Figure 1 Demonstrating bradycardia (54 bpm), slow and irregular $\mathrm{P}$ wave frequency due to sinus node disease, profound first-degree heart block of $640 \mathrm{~ms}$, broad left bundle branch block with leftward axis deviation. P waves occasionally concealed in preceding QRS complex (indicated by red arrows). 
Contributors WA drafted the first manuscript. JA edited the draft. FF and KSR came up with the original concept and edited the manuscript.

Competing interests None.

Patient consent Obtained.

Provenance and peer review Not commissioned; externally peer reviewed.

\section{REFERENCES}

1 Barold SS, llercil A, Leonelli F, et al. First-degree atrioventricular block. Clinical manifestations, indications for pacing, pacemaker management \& consequences during cardiac resynchronization. J Interv Card Electrophysiol 2006;17:139-52.

2 Cheng S, Keyes MJ, Larson MG, et al. Long-term outcomes in indviduals with prolonged PR interval or first-degree atrioventricular block. JAMA 2009;301:2571-7.

Copyright 2013 BMJ Publishing Group. All rights reserved. For permission to reuse any of this content visit http://group.bmj.com/group/rights-licensing/permissions.

BMJ Case Report Fellows may re-use this article for personal use and teaching without any further permission.

Become a Fellow of BMJ Case Reports today and you can:

- Submit as many cases as you like

- Enjoy fast sympathetic peer review and rapid publication of accepted articles

- Access all the published articles

- Re-use any of the published material for personal use and teaching without further permission

For information on Institutional Fellowships contact consortiasales@bmjgroup.com

Visit casereports.bmj.com for more articles like this and to become a Fellow 